\title{
Pengaruh Konsentrasi dan Lama Fermentasi Urin Sapi sebagai Pupuk Cair pada Pertumbuhan Bibit Karet (Hevea brasiliensis Muell. Arg.)
}

\section{(Effect of Cow Urine Concentration and Fermentation Duration as Liquid Fertilizer on Growth of Rubber [Hevea brasiliensis Muell. Arg.] Seedlings)}

\author{
Vinda Nawang Sari ${ }^{1)^{*}}$, Made Same ${ }^{2)}$, Yonathan Parapasan ${ }^{2)}$ \\ ${ }^{1)}$ Program Studi Produksi dan Manajemen Industri Perkebunan Politeknik Negeri Lampung dan ${ }^{2)}$ \\ Jurusan Budidaya Tanaman Perkebunan Politeknik Negeri Lampung, Jl. Soekarno-Hatta No. 10 \\ Rajabasa, Bandar Lampung, 35144 \\ E-mail:madesame@polinela.ac.id
}

\begin{abstract}
The aims of this research is to get the best concentration of cow urine as liquid organic fertilizer on rubber seed growth, to get the best fermentation time for cow urine as liquid organic fertilizer on the growth of rubber seedlings, and get the best interaction between concentration and cow urine fermentation as liquid organic fertilizer on the growth of rubber seedlings. The experiment was conducted in teaching farm of State Polytechnic of Lampung from January 2016 until June 2016. The treatments arranged in Randomized Block Design (RBD) with the factorial pattern consisting of two factors. The first factor was the concentration of cow urine, consisting of four levels: $15 \mathrm{cc.l} \mathrm{l}^{-1}, 30 \mathrm{cc.l} \mathrm{l}^{-1}, 45 \mathrm{cc} . \mathrm{l}^{-1}$ and $60 \mathrm{cc.} \mathrm{l}^{-1}$. The second factor was the duration of cow urine fermentation, consisting of five levels: 0 day, 7 day, 14 day, 21 day and 28 day. Rubber seedlings were used as plant indicator. Observations included plant height, number of petiole, stem diameter, stem girth, and dry weight of biomass. The results showed that the treatment of cow urine concentration had significant effect on plant height and number of petiole, but very significant effect on stem diameter, stem girth and dry weight of biomass. Likewise, the treatment of cow urine fermentation has significant effect on all observed variables except on the dry weight of biomass has a very significant effect. The interaction between treatment of cow urine concentration and cow urine fermentation did not significantly affect all variables except on dry weight of biomass had significant effect, i.e. cow urine concentration treatment of $45 \mathrm{cc.l}^{-1}$ and fermentation of cow urine for 28 days resulted in dry weight of biomass higher rubber seedlings.
\end{abstract}

Keywords: cow urine, fermentation, rubber seedlings

Diterima: 10 November 2016 / Disetujui: 24 Maret 2017 / Diterbitkan: 10 Mei 2017

\section{PENDAHULUAN}

Tanaman karet mempunyai peranan yang sangat penting dalam perekonomian di Indonesia karena banyak penduduk yang hidupnya mengandalkan komoditas ini. Tanaman yang memiliki nama latin Hevea brasiliensis Muell. Arg. merupakan salah satu hasil pertanian yang banyak menunjang perekonomian negara (Muhtaria et al., 2015; Marsantia et al., 2014; Sianturi et al., 2017). Total produksi karet nasional pada tahun 2013 berjumlah 581,5 juta ton dan meningkat 
menjadi 597,8 juta ton pada tahun 2014. Luas areal perkebunan karet seluruh Indonesia pada tahun 2013 mencapai total 529,9 juta ha dan pada tahun 2014 mencapai 543,3 juta ha (BPS, 2015). Dengan semakin meningkatnya produksi dan luas areal perkebunan karet seharusnya diiringi dengan peningkatan penyediaan dan mutu bibit pada saat di pembibitan, sehingga diharapkan produksi karet Indonesia dapat bersaing di pasar internasional.

Salah satu hambatan dalam pembibitan adalah media tumbuh pembibitan yang digunakan kurang tersedia unsur hara. Untuk memenuhi kebutuhan unsur hara pemberian pupuk perlu dilakukan pada tanaman sehingga diharapkan dapat tercapai pertumbuhan tanaman yang sehat dan baik (Desiana et al., 2013). Pemupukan merupakan salah satu usaha untuk meningkatkan pertumbuhan dan perkembangan tanaman karena dapat memperbaiki tingkat kesuburan tanah (Sukmawan et al., 2015). Jenis pupuk yang dapat digunakan salah satunya adalah pupuk organik.

Ketergantungan petani terhadap pupuk anorganik yang semakin mahal dan tidak ramah lingkungan merupakan masalah yang dihadapi saat ini. Alternatif yang dapat dilakukan oleh petani adalah dengan memanfaatkan pupuk organik yang mudah diperoleh. Pupuk organik dapat berasal dari kotoran hewan seperti ayam, kambing, kerbau, kuda, babi, dan sapi. Kotoran tersebut dapat berupa padat dan cair (urin ternak) dengan kandungan zat hara yang berbeda.

Pupuk cair urin sapi merupakan salah satu pupuk organik potensial sebagai sumber hara bagi tanaman seperti N, P dan K. Dari aspek haranya, cairan urin sapi memiliki kandungan hara yang lebih tinggi dibandingkan dengan kotoran padatnya (Hani \& Geraldine, 2016). Pemanfaatan urin sapi yang masih segar sebagai sumber hara tanaman jarang dilakukan karena baunya yang tidak sedap dan menimbulkan polusi udara sehingga harus terlebih dahulu dilakukan fermentasi selama satu atau dua minggu. Ternyata hasil fermentasi selain mengurangi bau menyengat yang tak sedap juga kualitasnya lebih baik dari urin sapi segar (Chaniago et al., 2017). Memperhatikan uraian di atas, maka dipandang perlu untuk melakukan penelitian tentang pengaruh konsentrasi dan lama fermentasi urin sapi sebagai pupuk cair pada pertumbuhan bibit karet.

\section{METODE PENELITIAN}

Penelitian ini dilaksanakan di kebun percobaan Politeknik Negeri Lampung, Rajabasa, Bandar Lampung. Penelitian dilaksanakan pada Januari 2016 sampai dengan Juni 2016. Alat yang digunakan dalam penelitian ini adalah cangkul, penggaris, jangka sorong, ember, gelas ukur, gembor, golok, arit, oven, kertas, dan alat tulis. Bahan yang digunakan adalah biji karet dengan klon GT 1, urin sapi, pasir, pelepah kelapa, EM4, mollase, tanah, tali rafia, Dithane M45, dan bambu. Penelitian dilaksanakan menggunakan Rancangan Acak Kelompok (RAK) berpola faktorial yang terdiri atas 2 faktor. Faktor pertama adalah konsentrasi urin sapi yang terdiri atas

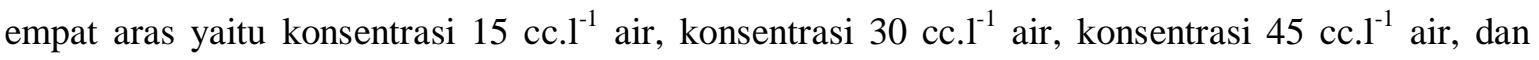
konsentrasi $60 \mathrm{cc.l}^{-1}$ air. Faktor kedua adalah lama fermentasi urin sapi yang terdiri atas lima aras yaitu fermentasi 0 hari, fermentasi 7 hari, fermentasi 14 hari, fermentasi 21 hari, dan fermentasi 28 
hari. Dengan demikian diperoleh 20 kombinasi perlakuan dan diulang 2 kali sehingga didapat 40 satuan percobaan.

\section{Persiapan areal}

Areal penelitian yang akan digunakan dibersihkan dari gulma dan sampah lainnya seluas $13 \mathrm{~m}$ x 9,8 m. Permukaan tanah pada areal pembibitan karet diratakan dengan menggunakan cangkul kemudian pembuatan media tanam yang dibagi menjadi 40 plot dengan ukuran plot $80 \mathrm{~cm}$ $\mathrm{x} 145 \mathrm{~cm}$.

\section{Persiapan pupuk cair}

Pupuk cair yang digunakan sebagai bahan perlakuan adalah urin sapi yang akan difermentasi kemudian tambahkan dengan EM4 $80 \mathrm{ml}$ dan mollases $60 \mathrm{ml}$. Fermentasi dilakukan setiap 1 minggu sekali agar mengaplikasikan ke tanaman dapat dilakukan secara bersamaan. Untuk fermentasi pertama dilakukan perlakuan dengan waktu fermentasi paling lama yaitu 28 hari. Selanjutnya untuk fermentasi 21 hari, 14 hari dan 7 hari. Untuk pemberian urin sapi diberikan dengan dosis $80 \mathrm{ml} \cdot \mathrm{tan}^{-1}$. Pemberian dilakukan dengan 2 kali, yaitu pada umur bibit 4 MST dan 8 MST dengan dosis 40 ml.tan ${ }^{-1}$.

\section{Pengecambahan}

Biji karet yang digunakan dalam penelitian ini menggunakan jenis klon GT 1 sebanyak 350 biji. Pembuatan bedengan pendederan biji karet dibuat dengan ukuran $2 \mathrm{~m}$ x $1 \mathrm{~m}$ kemudian di atas bedengan dihamparkan pasir setebal $5 \mathrm{~cm}$ secara merata sebagai media tanam. Dederan ditutup dengan menggunakan jerami kemudian disiram menggunakan gembor setiap pagi dan sore hari (disesuaikan).

\section{Pengamatan}

\section{a. Analisis NPK}

Analisis NPK diukur untuk mengetahui kandungan N, P, dan K yang ada pada urin sapi dari perlakuan fermentasi yaitu tanpa fermentasi, fermentasi 7 hari, 14 hari, 21 hari, dan 28 hari. Pengukuran dilakukan di Laboratorium Analisis Kimia Politeknik Negeri Lampung.

b. Tinggi tanaman

Tinggi bibit karet diukur mulai dari pangkal batang hingga titik tumbuh bibit karet dengan menggunakan penggaris dalam satuan $\mathrm{cm}$. Pengukuran tinggi tanaman dilakukan sejak tanaman berumur 4 minggu setelah tanam (MST).

c. Diameter batang

Pengukuran diameter batang tanaman karet dilakukan sekitar $10 \mathrm{~cm}$ dari permukaan tanah menggunakan jangka sorong dalam satuan $\mathrm{mm}$. 
d. Jumlah tangkai daun

Jumlah tangkai daun yang dihitung adalah seluruh daun yang telah membuka sempurna dengan ciri-ciri helaian daun sudah dalam posisi terbuka yang ditandai dengan terlihatnya tulangtulang daun seluruhnya bila diamati dari atas permukaan daun.

e. Lilit batang

Pengukuran lilit batang tanaman karet dilakukan sekitar $10 \mathrm{~cm}$ dari permukaan tanah menggunakan tali rafia dan penggaris dalam satuan $\mathrm{cm}$.

f. Bobot kering brangkasan

Bobot kering brangkasan akan diukur dengan menimbang seluruhbagian tanaman yang telah dikering anginkan kemudian diovenkan pada suhu $65{ }^{\circ} \mathrm{C}$ selama 48 jam hingga di peroleh bobot tetap.

\section{Analisis Data}

Hasil pengamatan yang berupa data dari lima variabel di analisis dengan Analysis of Variance (ANOVA). Selanjutnya apabila uji F terdapat perbedaan nyata, maka dilanjutkan dengan uji beda nyata terkecil (BNT) pada tingkat ketelitian $95 \%$.

\section{HASIL DAN PEMBAHASAN}

\section{Analisis Pendahuluan}

Hasil analisis uji laboratorium kandungan NPK pada urin sapi pada berbagai lama fermentasi disajikan pada Tabel 1. Tabel 1 memperlihatkan bahwa hasil analisis pendahuluan kandungan $\mathrm{N}$ total urin sapi pada perlakuan $\mathrm{F}_{0}$ dan $\mathrm{F}_{1}$ dan $\mathrm{F}_{4}$ relatif sama tetapi relatif lebih tinggi jika dibandingkan dengan perlakuan $F_{2}$ dan $F_{3}$. Hasil tertinggi terdapat pada perlakuan $F_{4}$ (fermentasi 28 hari) sebesar 0,669\%. Unsur nitrogen $(\mathrm{N})$ terutama berfungsi untuk merangsang pertumbuhan tanaman secara keseluruhan, terutama batang, cabang, dan daun. Menurut Sunaryanto \& Handayani (2016), sumber nitrogen sangat mempengaruhi pola fermentasi. Mikroorganisme akan mampu tumbuh dengan cepat dengan adanya unsur nitrogen (Rahmah et al., 2016) dalam bentuk organik dan beberapa membutuhkan unsur nitrogen yang absolut.

Hasil analisis pendahuluan kandungan $P$ total pada urin sapi pada perlakuan $F_{0}$ dan $F_{2}$ tidak berbeda nyata $(0,032 \%)$, begitu pula dengan perlakuan $\mathrm{F}_{1}$ dan $\mathrm{F}_{3}$, kandungan $\mathrm{P}$ totalnya relatif sama $(0,019 \%)$, namun kandungan P total pada perlakuan F4 (0,029 \%) relatif lebih tinggi jika dibandingkan dengan $F_{1}$ dan $F_{3}$, tetapi lebih rendah jika dibandingkan dengan $F_{0}$ dan $F_{2}$. Unsur fosfor $(\mathrm{P})$ bagi tanaman lebih banyak berfungsi untuk merangsang pertumbuhan akar, khususnya akar tanaman muda. Berbagai jenis protein tertentu memerlukan unsur fosfor sebagai bahan mentahnya. Fosfor juga berfungsi untuk membantu asimilasi dan pernafasan, sekaligus 
mempercepat pembungaan, pemasakan biji dan buah (Marviana \& Utami, 2014; Sudradjat et al., 2014).

Tabel 1. Hasil analisis kandungan NPK pada urin sapi

\begin{tabular}{cccc}
\hline Perlakuan & $\mathrm{N}(\%)$ & $\mathrm{P}(\%)$ & $\mathrm{K}(\%)$ \\
\hline $\mathrm{F}_{0}$ & 0,643 & 0,032 & 0,012 \\
$\mathrm{~F}_{1}$ & 0,64 & 0,019 & 0,012 \\
$\mathrm{~F}_{2}$ & 0,545 & 0,032 & 0,012 \\
$\mathrm{~F}_{3}$ & 0,504 & 0,019 & 0,012 \\
$\mathrm{~F}_{4}$ & 0,669 & 0,029 & 0,014
\end{tabular}

Sumber: Laboratorium Analisis Kimia Politeknik Negeri Lampung

Hasil analisis pendahuluan kandungan $\mathrm{K}$ total pada urin sapi pada perlakuan $\mathrm{F}_{0}, \mathrm{~F}_{1}, \mathrm{~F}_{2}$, dan $\mathrm{F}_{3}$ relatif sama $(0,012 \%)$. Namun relatif lebih rendah dibandingkan dengan perlakuan $(0,014 \%)$. Unsur kalium (K) membantu pembentukan protein dan karbohidrat. Pemberian Kalium memperkuat tanaman sehingga daun, bunga, dan buah tidak mudah mudah gugur. Selain itu, kalium juga membuat tanaman tahan terhadap kekeringan dan penyakit (Ruhnayat, 2007).

\section{Tinggi Tanaman}

Hasil analisis sidik ragam menunjukkan bahwa pemberian konsentrasi urin sapi dan lama fermentasi urin sapi berpengaruh nyata terhadap tinggi tanaman, tetapi tidak ada interaksi yang nyata di antara keduanya. Rerata tinggi tanaman pada beberapa konsentrasi urin sapi dan lama fermentasi urin sapi disajikan pada Tabel 2.

Tabel 2 memperlihatkan bahwa peningkatan perlakuan konsentrasi urin sapi berpengaruh terhadap variabel tinggi tanaman. Rerata tinggi tanaman tertinggi pada konsentrasi urin sapi yaitu perlakuan $\mathrm{U}_{3}$ (konsentrasi $45 \mathrm{cc}^{-1}{ }^{-1}$ air) sebesar $101,07 \mathrm{~cm}$, sedangkan hasil rerata terendah

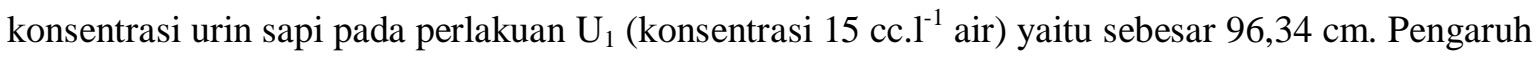
lama fermentasi urin sapi (Tabel 5) memperlihatkan bahwa semakin lama waktu fermentasi maka tinggi tanaman semakin meningkat. Rerata tinggi tanaman tertinggi pada perlakuan $\mathrm{F}_{4}$ (fermentasi 28 hari) sebesar 101,74 cm, sedangkan rerata terendah tinggi tanaman pada lama fermentasi urin sapi yaitu perlakuan $\mathrm{F}_{0}$ (tanpa fermentasi) sebesar $96,47 \mathrm{~cm}$.

Tinggi tanaman merupakan indikator pertumbuhan tanaman. Pertambahan tinggi tanaman merupakan salah satu bentuk adanya peningkatan pembelahan dan pembesaran sel dari hasil peningkatan fotosintat tanaman. Peningkatan tinggi tanaman merupakan hasil proses pembelahan, perpanjangan dan pembesaran sel. 
Tabel 2. Pengaruh konsentrasi urin sapi dan lama fermentasi urin sapi pada tinggi tanaman

\begin{tabular}{cccc}
\hline \multirow{2}{*}{ Perlakuan } & \multicolumn{2}{c}{ Tinggi tanaman $(\mathrm{cm})$} & Rerata \\
\cline { 2 - 3 } Konsentrasi & I & II & $96,34^{\mathrm{a}}$ \\
$\mathrm{U}_{1}$ & 96,72 & 95,97 & $100,16^{\mathrm{c}}$ \\
$\mathrm{U}_{2}$ & 100,42 & 99,91 & $101,07^{\mathrm{c}}$ \\
$\mathrm{U}_{3}$ & 100,52 & 101,63 & $98,78^{\mathrm{b}}$ \\
$\mathrm{U}_{4}$ & 101,20 & 96,36 & \\
BNT 0,05 & & 0,94 & $96,47^{\mathrm{a}}$ \\
Lama Fermentasi $_{\mathrm{F}_{0}}$ & 96,75 & 96,19 & $97,95^{\mathrm{ab}}$ \\
$\mathrm{F}_{1}$ & 99,89 & 96,02 & $100,18^{\mathrm{cd}}$ \\
$\mathrm{F}_{2}$ & 99,78 & 100,58 & $99,10^{\mathrm{bc}}$ \\
$\mathrm{F}_{3}$ & 100,46 & 97,75 & $101,74^{\mathrm{d}}$ \\
$\mathrm{F}_{4}$ & 101,69 & 101,79 & \\
BNT 0,05 & & 2,12 & \\
\hline
\end{tabular}

$\overline{\text { Keterangan: Angka-angka pada kolom yang sama diikuti oleh huruf yang tidak sama menunjukkan }}$ beda nyata dengan uji BNT pada taraf nyata $5 \%$

Tinggi tanaman pada perlakuan $\mathrm{U}_{3}$ (konsentrasi $45 \mathrm{cc}^{-1} \mathrm{l}^{-1}$ air) memberikan hasil terbaik dibandingkan dengan perlakuan lainnya. Hal ini diduga karena pemberian konsentrasi $45 \mathrm{cccl}^{-1}$ air mampu mensuplai unsur hara yang cukup bagi tanaman terutama unsur $\mathrm{N}$. Unsur $\mathrm{N}$ yang terdapat pada urin sapi merupakan unsur hara penting yang dibutuhkan untuk pertumbuhan vegetatif tanaman yaitu batang, daun, dan akar. Sesuai dengan pendapat Wahyono et al. (2016) bahwa proses pembelahan sel akan berjalan dengan cepat dengan adanya ketersediaan $\mathrm{N}$ yang cukup. Unsur $\mathrm{N}$ mempunyai peran utama untuk merangsang pertumbuhan secara keseluruhan dan khususnya pertumbuhan batang yang dapat memacu pertumbuhan tinggi bibit. Menurut Gardner \& Pearce (1991), tinggi tanaman lebih dipengaruhi oleh faktor genetik, namun faktor lingkungan seperti ketersediaan hara juga menjadi faktor pendukung lainnya dalam peningkatan pertumbuhan vegetatif tanaman. Unsur N, P, dan K yang terdapat pada kandungan urin berperan pada proses metabolisme yang dibutuhkan untuk pertumbuhan vegetatif tanaman.

Peningkatan pemberian berbagai macam urin sapi seperti pada perlakuan pemberian urin sapi sebanyak $60 \mathrm{cc}^{-l^{-1}}$ air, kecenderungan pertambahan tinggi tanaman terlihat tidak sebaik dengan pemberian urin sapi sebanyak $45 \mathrm{cc}^{-1}{ }^{-1}$ air. Hal ini terjadi karena konsentrasi yang diberikan dalam keadaan berlebih sehingga tidak dapat dimanfaatkan oleh tanaman dengan baik untuk 
meningkatkan pertambahan tinggi tanaman. Tanaman akan dapat tumbuh dan berproduksi dengan sempurna apabila unsur hara yang diperlukan cukup.

Pada perlakuan lama fermentasi urin sapi, tinggi tanaman bibit karet pada pemberian urin sapi yang telah difermentasi selama 28 hari memberikan pengaruh nyata. Urin sapi mengandung nitrogen dan zat perangsang tumbuh alami (Ilahi et al., 2016) dari golongan IAA, giberelin (GA) dan sitokinin. Nitrogen dalam urin sapi berbentuk senyawa amoniak sehingga memberikan pengaruh negatif terhadap pertumbuhan vegetatif tanaman karena suhunya yang tinggi. Suhu ini dapat diturunkan dengan menurunkan kadar amoniak dalam urin sapi dengan cara fermentasi, baik menggunakan bakteri pengurai atau dengan cara menyimpan urin tersebut. Penggunaan urin sapi sudah mulai populer di kalangan petani karena permintaan produk pertanian organik yang terus meningkat.

Lama fermentasi urin sapi selama 28 hari menghasilkan tinggi tanaman terbaik yaitu sebesar $101,74 \mathrm{~cm}$. Hal ini diduga karena pada waktu tersebut mikroorganisme telah terurai sehingga unsur hara telah tersedia bagi tanaman. Waryanti et al. (2103) melaporkan bahwa urin sapi yang difermentasi memperlihatkan adanya peningkatan komposisi jumlah dari unsur yang dikandungnya dibandingkan dengan yang tidak difermentasi. Urin sapi yang telah difermentasi dapat dijadikan sebagai nutrisi tanaman yang sebelumnya perlu dilakukan pengenceran. Pemberian pupuk yang tepat dalam hal macam, dosis, waktu pemupukan, dan cara pemberiannya akan dapat mendorong pertumbuhan dan peningkatan hasil tanaman baik kualitas maupun kuantitas.

\section{Diameter Batang}

Hasil analisis sidik ragam menunjukkan bahwa pemberian konsentrasi urin sapi berpengaruh sangat nyata terhadap diameter batang tetapi lama fermentasi urin sapi berpengaruh nyata terhadap diameter batang, tetapi tidak terjadi interaksi yang nyata di antara kedua faktor tersebut. Uji BNT pada tingkat ketelitian 95\% pada Tabel 3 memperlihatkan bahwa pemberian urin sapi dengan masing-masing konsentrasi dan lama fermentasi memberikan perbedaan yang nyata terhadap diameter batang. Diameter batang bibit karet terendah pada perlakuan $\mathrm{U}_{1}$ (konsentrasi 15 cc..$^{-1}$ air) sebesar $1,236 \mathrm{~cm}$. Perlakuan $\mathrm{U}_{2}$ (konsentrasi urin sapi $30 \mathrm{ccc}^{\mathrm{l}^{-1}}$ air) menghasilkan diameter batang sebesar $1,257 \mathrm{~cm}$ yang relatif hampir sama dengan perlakuan $\mathrm{U}_{4}$ (konsentrasi urin

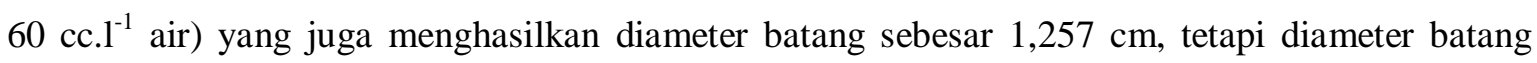
tertinggi terdapat pada perlakuan $\mathrm{U}_{3}$ (konsentrasi $45 \mathrm{cc}^{-1} \mathrm{l}^{-1}$ air) sebesar $1,340 \mathrm{~cm}$.

Jika jaringan tumbuhan mengandung unsur hara tertentu dengan konsentrasi lebih tinggi dari konsentrasi yang dibutuhkan untuk pertumbuhan maksimum, maka pada kondisi ini dikatakan tumbuhan dalam kondisi konsumsi mewah atau luxury consumption (Minardi et al., 2013; Novita

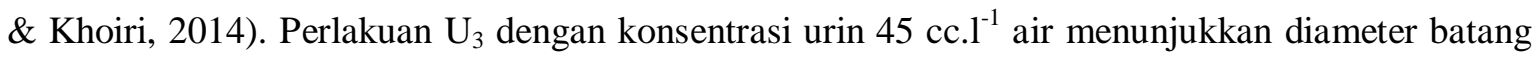
bibit karet terbesar yaitu $1,340 \mathrm{~cm}$. Hal ini diduga karena pada konsentrasi tersebut unsur hara tersedia sangat berlimpah yang dibutuhkan bagi tanaman sehingga pertumbuhan maksimum terjadi. 
Tabel 3. Pengaruh konsentrasi urin sapi dan lama fermentasi urin sapi pada diameter batang

\begin{tabular}{cccc}
\hline \multirow{2}{*}{ Perlakuan } & \multicolumn{2}{c}{ Diameter batang $(\mathrm{cm})$} & \multirow{2}{*}{ Rerata } \\
\cline { 2 - 3 } & I & II & $1,236^{\mathrm{a}}$ \\
Konsentrasi & 1,236 & 1,237 & $1,252^{\mathrm{ab}}$ \\
$\mathrm{U}_{1}$ & 1,290 & 1,214 & $1,340^{\mathrm{c}}$ \\
$\mathrm{U}_{2}$ & 1,353 & 1,328 & $1,257^{\mathrm{b}}$ \\
$\mathrm{U}_{3}$ & 1,247 & 1,268 & \\
$\mathrm{U}_{4}$ & & 0,94 & \\
BNT 0,05 & &
\end{tabular}

Lama Fermentasi

$\begin{array}{llll}\mathrm{F}_{0} & 1,253 & 1,202 & 1,227^{\mathrm{a}} \\ \mathrm{F}_{1} & 1,285 & 1,236 & 1,260^{\mathrm{b}} \\ \mathrm{F}_{2} & 1,255 & 1,254 & 1,255^{\mathrm{b}} \\ \mathrm{F}_{3} & 1,324 & 1,257 & 1,290^{\mathrm{c}} \\ \mathrm{F}_{4} & 1,291 & 1,359 & 1,325^{\mathrm{d}}\end{array}$

BNT 0,05

2,12

$\overline{\text { Keterangan: Angka-angka pada kolom yang sama diikuti oleh huruf yang tidak sama menunjukkan }}$ beda nyata dengan uji BNT pada taraf nyata $5 \%$

Efisiensi pemupukan yang optimal dapat dicapai apabila pupuk diberikan dalam jumlah yang sesuai dengan kebutuhan (Manshuri, 2010). Bila pupuk yang diberikan terlalu banyak, maka larutan tanah akan terlalu pekat sehingga dapat mengakibatkan keracunan dan penurunan pertumbuhan tanaman. Hal itu menunjukkan bahwa pada perlakuan $\mathrm{U}_{4}$ dengan konsentrasi $60 \mathrm{cc}^{-l^{-1}}$ air menghasilkan diameter batang sebesar $1,257 \mathrm{~cm}$, yang berarti konsentrasi urin sapi tertinggi tidak menjamin peningkatan diameter batang.

Pemberian urin sapi sebanyak 45 cc.l $^{-1}$ air diduga mampu mensuplai unsu hara yang diserap tanaman dengan baik terutama unsur N. Pemberian pupuk dengan kadar nitrogen yang tinggi dapat mempercepat pertumbuhan dan perkembangan organ tanaman sehingga lebih cepat mengalami pertambahan jumlah daun dan ukuran luas daun (Nasaruddin \& Rosmawati., 2010). Selain itu juga nitrogen yang terkandung dalam pupuk organik cair berperan sebagai penyusun protein sedangkan fosfor dan kalsium berperan dalam memacu pembelahan jaringan meristem dan merangsang pertumbuhan akar dan perkembangan daun. Akibatnya, tingkat absorbsi unsur hara dan air oleh tanaman sampai batas optimumnya akan digunakan untuk pembelahan, perpanjangan dan diferensiasi sel (Syahputra et al., 2013). 
Lama fermentasi urin sapi memberikan perbedaan yang nyata terhadap diameter batang. Perlakuan $\mathrm{F}_{0}$ (tanpa fermentasi) menunjukkan diameter batang bibit karet terendah yaitu sebesar 1,227 cm, sedangkan pada perlakuan $\mathrm{F}_{4}$ (fermentasi 28 hari) menghasilkan diameter batang tertinggi yaitu sebesar $1,325 \mathrm{~cm}$. Lama fermentasi selama 28 hari diduga mampu mensuplai dan memenuhi unsur hara yang dibutuhkanbagi tanaman.

Lama fermentasi selama 28 hari diduga mampu mensuplai dan memenuhi unsur hara yang dibutuhkan bagi tanaman. Kandungan unsur hara pada ternak yang penting untuk tanaman antara lain unsur hara N, P, dan K. Ketiga unsur tersebut yang paling banyak dibutuhkan oleh tanaman, dan masing-masing unsur hara tersebut memiliki fungsi yang berbeda dan saling melengkapi bagi tanaman, dengan demikian pertumbuhan menjadi lebih optimal.

\section{Jumlah Tangkai Daun}

Hasil analisis sidik ragam menunjukkan bahwa pemberian konsentrasi urin sapi dan lama fermentasi urin sapi berpengaruh nyata terhadap jumlah tangkai daun, tetapi tidak terdapat interaksi yang nyata di antara keduanya. Tabel 4 memperlihatkan bahwa peningkatan perlakuan konsentrasi urin sapi berpengaruh terhadap variabel jumlah tangkai daun. Rerata jumlah tangkai daun tertinggi pada konsentrasi urin sapi yaitu perlakuan $\mathrm{U}_{3}$ (konsentrasi $45 \mathrm{cc.l}^{-1}$ air) sebesar 14,90, sedangkan untuk rerata tangkai daun terendah yaitu sebesar 13,47 pada perlakuan $\mathrm{U}_{4}$ (konsentrasi $60 \mathrm{cc.l}^{-1}$ air). Pengaruh lama fermentasi urin sapi memperlihatkan bahwa rerata jumlah tangkai daun tertinggi pada perlakuan $\mathrm{F}_{4}$ (fermentasi 28 hari) sebesar 14,67, sedangkan rerata terendah jumlah tangkai daun pada lama fermentasi urin sapi yaitu perlakuan $\mathrm{F}_{3}$ (fermentasi 21 hari) sebesar 12,58.

Hasil analisis sidik ragam dari pemberian berbagai macam konsentrasi urin sapi berbeda nyata terhadap jumlah tangkai daun bibit karet. Pemberian urin sapi sebanyak $45 \mathrm{cc.l}^{-1}$ air berbeda nyata terhadap perlakuan konsentrasi lainnya. Hal ini diduga pada kosentrasi mensuplai unsur hara yang dibutuhkan bibit karet seperti unsur nitrogen dan fosfat yang sangat berpengaruh terhadap pertambahan jumlah daun tanaman, selain itu pembentukan jumlah tangkai daun juga diduga dipengaruhi oleh tinggi tanaman tersebut.

Pemberian urin sapi sebanyak $45 \mathrm{cc.l}^{-1}$ air diduga mampu mensuplai unsur hara yang dibutuhkan bibit karet seperti unsur nitrogen dan fosfat yang sangat berpengaruh terhadap pertambahan jumlah tangkai daun tanaman, selain itu pembentukan jumlah tangkai daun juga

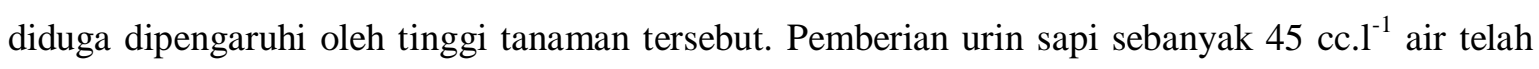
mampu memberikan ketersediaan unsur hara yang optimal sehingga pemberian unsur hara yang berlebih dari kebutuhan tanaman dapat mengganggu pertumbuhan tanaman tersebut. Lama fermentasi urin sapi selama 28 hari menghasilkan jumlah tangkai daun terbaik yaitu sebesar 15,08. Hal ini diduga karena pada waktu tersebut mikroorganisme telah terurai sehingga unsur hara telah tersedia. Salah satu fungsi pupuk organik adalah memperbaiki struktur tanah serta menyediakan hara bagi tanaman. Unsur hara sangat diperlukan oleh tanaman untuk membentuk suatu senyawa 
yang diperlukan untuk pertumbuhan tanaman melalui pembelahan dan pembesaran sel. Unsur hara yang berperan besar dalam pertumbuhan dan perkembangan daun yaitu nitrogen.

Tabel 4. Pengaruh konsentrasi urin sapi dan lama fermentasi urin sapi pada jumlah tangkai daun

\begin{tabular}{cccc}
\hline \multirow{2}{*}{ Perlakuan } & \multicolumn{2}{c}{ Jumlah tangkai daun (buah) } & \multirow{2}{*}{ Rerata } \\
\cline { 2 - 3 } & I & II & $13,53^{\mathrm{a}}$ \\
\hline Konsentrasi & 13,93 & 13,13 & $13,63^{\mathrm{a}}$ \\
$\mathrm{U}_{1}$ & 13,53 & 13,73 & $14,90^{\mathrm{b}}$ \\
$\mathrm{U}_{2}$ & 15,20 & 14,60 & $13,47^{\mathrm{a}}$ \\
$\mathrm{U}_{3}$ & 13,93 & 13,00 & \\
$\mathrm{U}_{4}$ & & 0,35 & $13,63^{\mathrm{b}}$ \\
BNT 0,05 & 14,00 & $13,25^{\mathrm{b}}$ & $13,63^{\mathrm{b}}$ \\
Lama Fermentasi $_{\mathrm{F}_{0}}$ & 13,83 & $13,42^{\mathrm{b}}$ & $14,17^{\mathrm{b}}$ \\
$\mathrm{F}_{1}$ & 13,83 & $14,17^{\mathrm{b}}$ & $12,58^{\mathrm{a}}$ \\
$\mathrm{F}_{2}$ & 13,58 & $12,58^{\mathrm{a}}$ & $14,67^{\mathrm{c}}$ \\
$\mathrm{F}_{3}$ & 15,50 & $14,67^{\mathrm{c}}$ & \\
$\mathrm{F}_{4}$ & & 0,44 & \\
BNT 0,05 & & &
\end{tabular}

Keterangan: Angka-angka pada kolom yang sama diikuti oleh huruf yang tidak sama menunjukkan beda nyata dengan uji BNT pada taraf nyata $5 \%$

\section{Lilit Batang}

Hasil analisis sidik ragam menunjukkan bahwa pemberian konsentrasi urin sapi berpengaruh sangat nyata terhadap lilit batang, tetapi lama fermentasi urin sapi berpengaruh nyata terhadap lilit batang, tetapi tidak memberikan interaksi yang nyata di antara keduanya. Tabel 5 memperlihatkan bahwa peningkatan perlakuan konsentrasi urin sapi berpengaruh terhadap variabel lilit batang. Rerata lilit batang tertinggi pada konsentrasi urin sapi yaitu perlakuan $\mathrm{U}_{3}$ (konsentrasi $45 \mathrm{cc}^{-l^{-1}}$ air) sebesar $4,209 \mathrm{~cm}$. Sedangkan hasil rerata terendah konsentrasi urin sapi pada perlakuan $\mathrm{U}_{1}$ (konsentrasi $15 \mathrm{cc}^{-1} \mathrm{I}^{-1}$ air) yaitu sebesar $3,882 \mathrm{~cm}$. Pengaruh lama fermentasi urin sapi (Tabel 5) memperlihatkan bahwa semakin lama waktu fermentasi maka tinggi tanaman semakin meningkat. Rerata tinggi tanaman tertinggi pada perlakuan $\mathrm{F}_{4}$ (fermentasi 28 hari) sebesar 4,160 $\mathrm{cm}$, sedangkan rerata terendah tinggi tanaman pada lama fermentasi urin sapi yaitu perlakuan $\mathrm{F}_{0}$ (tanpa fermentasi) sebesar $3,854 \mathrm{~cm}$. 
Tabel 5. Pengaruh konsentrasi urin sapi dan lama fermentasi urin sapi pada lilit batang

\begin{tabular}{cccc}
\hline \multirow{2}{*}{ Perlakuan } & \multicolumn{2}{c}{ Lilit batang $(\mathrm{cm})$} & \multirow{2}{*}{ Rerata } \\
\cline { 2 - 3 } Konsentrasi & I & II & $3,882^{\mathrm{a}}$ \\
$\mathrm{U}_{1}$ & 3,881 & 3,883 & $3,931^{\mathrm{ab}}$ \\
$\mathrm{U}_{2}$ & 4,050 & 3,812 & $4,209^{\mathrm{c}}$ \\
$\mathrm{U}_{3}$ & 4,249 & 4,169 & $3,948^{\mathrm{b}}$ \\
$\mathrm{U}_{4}$ & 3,916 & 3,981 & \\
BNT 0,05 & & 0,54 & $3,854^{\mathrm{a}}$ \\
Lama Fermentasi & 3,934 & 3,775 & $3,957^{\mathrm{b}}$ \\
$\mathrm{F}_{0}$ & 4,033 & 3,881 & $3,939^{\mathrm{b}}$ \\
$\mathrm{F}_{1}$ & 3,941 & 3,938 & $4,052^{\mathrm{c}}$ \\
$\mathrm{F}_{2}$ & 4,158 & 3,946 & $4,160^{\mathrm{d}}$ \\
$\mathrm{F}_{3}$ & 4,053 & 4,268 & \\
$\mathrm{~F}_{4}$ & & 0,67 & \\
BNT 0,05 & & & \\
\hline
\end{tabular}

Keterangan: Angka-angka pada kolom yang sama diikuti oleh huruf yang tidak sama menunjukkan beda nyata dengan uji BNT pada taraf nyata $5 \%$

Uji BNT pada taraf nyata 5\% menunjukkan bahwa pemberian urin sapi dengan masingmasing konsentrasi dan lama fermentasi terdapat perbedaan yang nyata terhadap lilit batang. Lilit batang bibit karet terendah pada perlakuan $U_{1}$ (konsentrasi 15 cc. $^{-1}$ air) sebesar 3,882 cm.

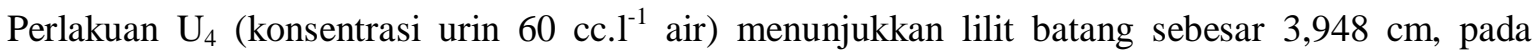
perlakuan $\mathrm{U}_{2}$ (konsentrasi urin sapi $30 \mathrm{cc.l}^{-1}$ air) menunjukkan diameter batang sebesar 3,931 cm,

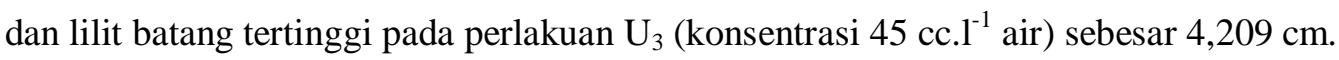

Pada pemberian konsentrasi urin sapi sebesar $45 \mathrm{cc.l}^{-1}$ air menghasilkan lilit batang tertinggi. Hal ini diduga karena terjadi karena pada pemberian konsentrasi urin sapi sebesar 45 cc. $\mathrm{l}^{-1}$ air mampu menyediakan unsur esensial bagi pertumbuhan tanaman, terutama unsur $\mathrm{N}$. Pemberian pupuk dengan kadar nitrogen yang tinggi dapat mempercepat pertumbuhan dan perkembangan organ tanaman sehingga lebih cepat mengalami pertambahan jumlah daun dan ukuran luas daun (Nasaruddin \& Rosmawati, 2010). Pemberian urin sapi dengan lama fermentasi yang berbeda berpengaruh nyata terhadap diameter batang. Perlakuan $\mathrm{F}_{0}$ (fermentasi 0 hari/tanpa fermentasi) menunjukkan lilit batang bibit karet terendah yaitu sebesar 3,854, cm. Sedangkan pada perlakuan $\mathrm{F}_{4}$ (fermentasi 28 hari) menunjukkan lilit batang tertinggi yaitu sebesar $4,16 \mathrm{~cm}$. Dari hasil pengamatan, pemberian urin sapi berpengaruh pada lilit batang khususnya yang telah 
difermentasi selama 28 hari memberikan hasil yang terbaik. Pupuk organik cair mengandung unsur kalium yang berperan penting dalam setiap proses metabolisme tanaman, yaitu dalam sintesis asam amino dan protein dari ion-ion amonium serta berperan dalam memelihara tekanan turgor dengan baik sehingga memungkinkan lancarnya proses-proses metabolisme dan menjamin kesinambungan pemanjangan sel (Ohorella , 2011; Supartha et al., 2012).

Urin sapi yang telah difermentasi dapat digunakan sebagai nutrisi tanaman sebagai alternatif pengganti pupuk buatan. Fermentasi merupakan aktivitas mikroorganisme baik aerob maupun anaerob yang mampu mengubah atau mentransformasikan senyawa kimia ke substrat organik. Fermentasi dapat terjadi karena ada aktivitas mikroorganisme penyebab fermentasi pada substrat organik yang sesuai, proses ini dapat menyebabkan perubahan sifat bahan tersebut. Beberapa sifat urin sapi yang difermentasi terlihat bahwa adanya peningkatan komposisi jumlah dari unsur yang dikandung dibandingkan dengan yang tidak difermentasi dan juga urin sapi yang telah difermentasi dapat dijadikan sebagai nutrisi tanaman yang sebelumnya perlu dilakukan pengenceran.

\section{Bobot Kering Brangkasan}

Hasil analisis sidik ragam bobot kering brangkasan menunjukkan bahwa pengaruh tunggal perlakuan konsentrasi urin sapi dan lama fermentasi urin sapi serta interaksi di antara keduanya berpengaruh sangat nyata terhadap bobot kering brangkasan (Tabel 6).

Tabel 6. Interaksi antara konsentrasi dan lama fermentasi urin sapi pada bobot kering brangkasan

\begin{tabular}{cccccc}
\hline \multirow{2}{*}{ Konsentrasi } & \multicolumn{5}{c}{ Lama fermentasi } \\
\cline { 2 - 5 } & $\mathrm{F}_{0}$ & $\mathrm{~F}_{1}$ & $\mathrm{~F}_{2}$ & $\mathrm{~F}_{3}$ & $\mathrm{~F}_{4}$ \\
\hline $\mathrm{U}_{1}$ & $148,75^{\text {abc }}$ & $181,85^{\text {efgh }}$ & $173,25^{\text {defg }}$ & $179,55^{\text {efgh }}$ & $136,90^{\text {ab }}$ \\
$\mathrm{U}_{2}$ & $196,25^{\text {gh }}$ & $181,15^{\text {efgh }}$ & $134,80^{\mathrm{a}}$ & $168,35^{\text {cdef }}$ & $192,50^{\text {fgh }}$ \\
$\mathrm{U}_{3}$ & $160,10^{\text {bcde }}$ & $188,05^{\text {fgh }}$ & $192,40^{\text {fgh }}$ & $225,35^{\mathrm{i}}$ & $259,25^{\mathrm{j}}$ \\
$\mathrm{U}_{4}$ & $154,00^{\text {abcd }}$ & $202,25^{\mathrm{hi}}$ & $161,25^{\text {bcde }}$ & $168,50^{\text {cdef }}$ & $180,75^{\text {efgh }}$ \\
BNT 0,05 & & & 24,43 & &
\end{tabular}

Keterangan: Angka-angka pada kolom yang sama diikuti oleh huruf yang tidak sama menunjukkan beda nyata dengan uji BNT pada taraf nyata $5 \%$

Uji BNT pada taraf nyata 5\% menunjukkan bahwa bobot kering berangkasan tertinggi yaitu pada perlakuan $\mathrm{U}_{3} \mathrm{~F}_{4}$ sebesar 259,25 gram. Wachjar \& Kadarisman (2007) melaporkan bahwa nitrogen dapat merangsang pembentukan auksin yang berfungsi mempercepat pembelahan sel yang diikuti meningkatnya kemampuan proses pengambilan air karena perbedaan tekanan. Hal ini 
menyebabkan jumlah sel bertambah, volume akan meningkat sejalan dengan pemanjangan dan pembesaran sel.

Pemberian konsentrasi sebesar $45 \mathrm{cc}^{-1}$ air dengan lama fermentasi 28 hari memberikan pengaruh nyata terhadap bobot kering berangkasan bibit karet. Hal ini diduga karena pertambahan bobot kering tanaman seiring dan dipengaruhi oleh pertumbuhan organ vegetatif dari tanaman. Bobot kering tanaman yang dihasilkan pada pertumbuhan didukung oleh pertumbuhan organ vegetatif tanaman. Gardner \& Pearce (1991) menyatakan bahwa bobot kering brangkasan mencerminkan akumulasi senyawa organik yang berhasil disintesis tanaman dari senyawa anorganik yaitu air dan $\mathrm{CO}_{2}$, peningkatan bobot kering brangkasan terjadi karena penyerapan hara yang meningkat. Bobot kering brangkasan bibit yang terbentuk mencerminkan banyaknya fotosintat sebagai hasil fotosintesis, karena bobot kering brangkasan sangat tergantung pada laju fotosintesis. Pemberian bahan organik dapat menyebabkan struktur tanah menjadi lebih remah, dengan demikian perkembangan akar akan menjadi lebih baik, sehingga akan meningkatkan berat kering bibit. Hal ini sesuai dengan pemberian urin sapi dengan konsentrasi tinggi dapat meningkatkan bobot kering berangkasan bibit itu sendiri

\section{KESIMPULAN DAN SARAN}

\section{Kesimpulan}

Pemberian konsentrasi terbaik $45 \mathrm{cc}^{-1}{ }^{-1}$ air urin sapi sebagai pupuk organik cair dapat mempengaruhi pertumbuhan bibit karet pada pengamatan tinggi tanaman, diameter batang, jumlah tangkai tangkai daun, dan lilit batang. Waktu fermentasi terbaik 28 hari urin sapi sebagai pupuk organik cair dapat mempengaruhi pertumbuhan bibit karet pada pengamatan tinggi tanaman, diameter batang, jumlah tangkai daun, dan lilit batang. Pemberian konsentrasi $45 \mathrm{cc.l}^{-1}$ air dan waktu fermentasi 28 hari urin sapi terbaik sebagai pupuk organik cair menunjukkan adanya interaksi terhadap bobot kering berangkasan bibit karet.

\section{Saran}

Berdasarkan hasil penelitian tentang konsentrasi dan lama fermentasi urin sapi sebagai pupuk cair maka perlu dilakukan penelitian lanjutan pada tanaman dan pupuk organik cair yang berbeda.

\section{DAFTAR PUSTAKA}

Chaniago, N., Safruddin, \& Kurniawan, D. (2017). Respon pertumbuhan dan produksi tanaman tomat (Lycopersicum esculentum Mill.) terhadap pemberian pupuk kandang sapi dan fermentasi urin sapi. Bernas, 13(2), 23-29. 
Desiana, C., Banuwa, I. S., Evizal, R., \& Yusnaini, S. (2013). Pengaruh pupuk organik cair urin sapi dan limbah tahu terhadap pertumbuhan bibit kakao (Theobroma cacao L.). Jurnal Agrotek Tropika, 1(1), 113-119.

Gardner, F. P., \& Pearce, R. B. (1991). Fisiologi Tanaman Budidaya. Jakarta: Universitas Indonesia Press.

Hani, A. \& Geraldine, L. P. (2016). Pengaruh jarak tanam dan pemberian pupuk cair urin kambing terhadap pertumbuhan awal manglid (Magnolia champaca (L.) Baill. Ex. Pierre). Jurnal Wasian, 3(2), 51-58.

Ilahi, R., Ariani, E., \& Saputra, S. I. (2016). The effect of cow urine and cocoa peel's compost for the growth of palm oil (Elaeis guineensis Jacq.) in the main nursery. Jurnal Online Mahasiswa Bidang Pertanian, 3(1), 1-16.

Manshuri, A. G. (2010). Pemupukan N, P, dan K pada kedelai sesuai kebutuhan tanaman dan daya dukung lahan. Jurnal Penelitian Pertanian Tanaman Pangan, 29(3), 171-179.

Marsantia, G., Suroso, E., \& Utomo, T. P. (2014). Kajian strategi kebijakan industri olahan karet ribbed smoked sheet (RSS) berbahan baku lateks kebun dalam upaya peningkatan mutu produk. Jurnal Teknologi \& Industri Hasil Pertanian, 19(1), 84-95.

Marviana, D. D., \& Utami, L. B. (2014). Respon pertumbuhan tanaman terung (Solanum melongena L.) terhadap pemberian kompos berbahan dasar tongkol jagung dan kotoran kambing sebagai materi pembelajaran biologi versi kurikulum 2013. J. Jupemasi-pbio (1), 1, 161-166.

Minardi, S., Winarno, J., \& Abdillah, A. H. N. (2013). Efek perimbangan pupuk organik dan pupuk anorganik terhadap sifat kimia tanah andisol tawangmangu dan hasil tanaman wortel (Daucus carota L.). Sains Tanah-Journal of Soil Science and Agroclimatology, 6(2), 111-116.

Muhtaria, C., Supriyatdi, D., \& Rofiq, M. (2015). Pengaruh konsentrasi stimulan dan intensitas sadap pada produksi lateks tanaman karet seedling (Hevea brasiliensis Muell. Arg.). Jurnal Agro Industri Perkebunan, 3(1), 59-68.

Nasaruddin \& Rosmawati. (2010). Pengaruh pupuk organik cair (POC) hasil fermentasi daun gamal, batang pisang dan sabut kelapa terhadap pertumbuhan bibit kakao. Jurnal Agrisistem, 7(1), 29-37.

Novita, R. Y., \& Khoiri, M. A. (2014). Efek pemberian pupuk kascing dan urea terhadap pertumbuhan bibit kakao (Theobroma cacao L.). Jurnal Online Mahasiswa Bidang Pertanian, 1(2), 1-11.

Ohorella, Z. (2011). Respon pertumbuhan dan produksi tanaman kedelai pada sistem olah tanah yang berbeda. Jurnal Agronomika, 1(2), 92-98.

Rahmah, A., Izzati, M., \& Parman, S. (2014). Pengaruh pupuk organik cair berbahan dasar limbah sawi putih (Brassica chinensis L.) terhadap pertumbuhan tanaman jagung manis. Buletin Anatomi dan Fisiologi dh Sellula, 22(1), 65-71.

Rizki, K., \& Rasyad, A. (2014). Pengaruh pemberian urin sapi yang difermentasi terhadap pertumbuhan dan produksi tanaman sawi hijau (Brassica rafa). Jurnal Online Mahasiswa Bidang Pertanian, 1(2), 1-8. 
Sahputra, A., Barus, A., \& Sipayung, R. (2013). Pertumbuhan dan produksi bawang merah (Allium ascalonicum L.) terhadap pemberian kompos kulit kopi dan pupuk organik cair. AGROEKOTEKNOLOGI, 2(1), 26-35.

Sianturi, S. S., Yulida, R., \& Sayamar, E. (2017). Analisis penyuluhan dan keberdayaan petani karet pola swadaya di kecamatan pujud kabupaten rokan hilir. IJAE (Jurnal Ilmu Ekonomi Pertanian Indonesia), 7(1), 114-131.

Sudradjat, Sukmawan, Y., \& Sugiyanta. (2014). Influence of manure, nitrogen, phosphorus and potassium fertilizer application on growth of one-year-old oil palms on marginal soil in Jonggol, Bogor, Indonesia. Journal of Tropical Crop Science, 1(2), 18-24.

Sukmawan, Y., Sudradjat, \& Sugiyanta. (2015). Peranan pupuk organik dan NPK majemuk terhadap pertumbuhan kelapa sawit TBM 1 di lahan marginal. J. Agron. Indonesia, 43(3), 242-249.

Sunaryanto, R., \& Handayani, B. H. (2016). Penentuan kombinasi medium terbaik galaktosa dan sumber nitrogen pada proses produksi etanol. Jurnal Bioteknologi \& Biosains Indonesia (JBBI), 2(1), 20-26.

Supartha, I. N. Y., WIJANA, G., \& ADNYANA, G. M. (2012). Aplikasi jenis pupuk organik pada tanaman padi sistem pertanian organik. E-Jurnal Agroekoteknologi Tropika, 1(2), 98-106.

Supriyanto, S., Muslimin, M., \& Umar, H. (2014). Pengaruh berbagai dosis pupuk organik cair urin sapi terhadap pertumbuhan semai jabon merah (Anthocephalus macrophyllus (Roxb.) Havil). Jurnal Warta Rimba, 2(2), 149-157.

Wachjar, A., \& Kadarisman, L. (2007). Pengaruh kombinasi pupuk organik cair dan pupuk anorganik serta frekuensi aplikasinya terhadap pertumbuhan tanaman kakao (Theobroma cacao L.) belum menghasilkan. Bul. Agronomi, 35(3), 212-216.

Wahyono, T., Yetti, H., \& Yoseva, S. (2016). Studi pemberian kompos tandan kompos kelapa sawit dan pupuk urea terhadap pertumbuhan bibit buah naga (Hylocereus Costaricensis). Jurnal Online Mahasiswa Bidang Pertanian, 2(2), 1-13.

Waryanti, A., \& Sutrisno, E. (2013). Studi pengaruh penambahan sabut kelapa pada pembuatan pupuk cair dari limbah air cucian ikan terhadap kualitas unsur hara makro (CNPK). Jurnal Teknik Lingkungan, 2(4), 1-7. 